\title{
LOCALIZATION OF ACTIN IN POLLEN TUBES OF ORNITHOGALUM VIRENS L.
}

\author{
MAŁgOrZata StęPKA ${ }^{1}$, FABricio CiAMPOLINI ${ }^{2}$, MAURO CRESTI $^{2}$, MARIA CHARZYŃSKA $^{1}$ \\ ${ }^{1}$ Department of Plant Anatomy and Cytology, Warsaw University, \\ Krakowskie Przedmieście 26/28, PL-00-927 Warszawa, Poland \\ ${ }^{2}$ Department of Environmental Biology, University of Siena, \\ P.A. Mattioli 4, 53100 Siena, Italy
}

(Received: January 19, 1999. Accepted: May 27, 1999)

\begin{abstract}
The germinating pollen grain (in vivo on the stigma or in vitro in germination medium) forms a pollen tube which transports the vegetative nucleus and generative cell/two sperm cells participating in the process of double fertilization. The growth of the tube and the transport of organelles and the cells occur due to two major motor systems existing in the pollen tubes of higher plants: the tubuline-dynein/kinesin and the actin-myosin system. In pollen tubes of Ornithogalum virens the actin filaments were labelled with TRITC-phalloidin $(2 \mu \mathrm{g} / \mathrm{ml})$ in the PIPES buffer and the $10 \%$ sucrose, without the fixative and DMSO. Omission of the fixative and permeabilizing agent (DMSO) allowed better preservation of the structure, and the "fluorescence" of actin was observed in living pollen tubes. Observations in CLSM (confocal laser scanning microscope) showed that actin is distributed in the vicinity of the cell membrane. This could support the view that actin filaments and the plasmalemma form the pollen tube cortex along which the cytoplasmic movement of organelles, and cell transport occurs.
\end{abstract}

KEY WORDS: actin, cortex, phalloidin, pollen tube.

\section{INTRODUCTION}

The sperm cells of angiosperms lack the locomotory apparatus like flagella or cilia. Instead the pollen tube as a specialized structure delivers the male gametes to the embryo sac. In the pollen tube (= vegetative cell) it was demonstrated both the presence of cytoskeletal elements (microtubules and microfilaments) and motor proteins (kinesin, dynein, and myosin). The observations indicate that the movement of cytoplasm and the migration of vegetative nucleus and generative cell/ sperm cells, are based on two locomotory systems: microtubule-kinesin-dynein and actin-myosin system.

The presence of actin filaments in pollen tube was first demonstrated by Condeelis (1974) in electron microscope. Since that time many methods were used to visualize actin filaments in pollen and pollen tubes. For review see Pierson and Cresti (1992). However, most of these methods caused the disruption of actin filament organization and it is difficult to find a proper procedure for good preservation of actin cytoskeleton. Nevertheless, the most popular methods of actin localization use flourochrome labelled phallotoxins (FLPh), which bind specifically to the filamentous actin (F-actin).

In wholemount preparations of the pollen tubes, actin was visualized after formaldehyde fixation, prior to labelling with FLPh (e.g. Perdue and Parthasarathy 1985; Pierson et al. 1986). However, the formaldehyde fixatives damaged the structure of the pollen tube cytoplasm and disrupted the organization of actin filaments (Lancelle et al. 1987). The procedure omitting the fixative, developed by Pierson (1988), is based on the method of direct staining of actin in non-fixed pollen tubes, with rhodamine-labelled-phalloidin in a permeabilizing agent - dimethyl sulphoxide (DMSO). The Factin patterns visualized by this method were much finer and more detailed in comparison to those treated with conventional fixatives containing formaldehyde (Pierson 1988; Heslop-Harrison and Heslop-Harrison 1989, 1991, 1992). The aim of our work was to visualize the structure and the organization of actin in pollen tubes of Ornithogalum virens using the modification of Piersons method (1988).

\section{MATERIAL AND METHODS}

Pollen grains of Ornithogalum virens L. (plant collection in a greenhouse, Department of Plant Anatomy and Cytology, Warsaw University) were collected from dehisced anthers. Pollen was germinated in modified Brewbaker and Kwack's (1963) medium: $0.01 \% \quad \mathrm{H}_{3} \mathrm{BO}_{3}, 0.043 \% \quad \mathrm{Ca}\left(\mathrm{NO}_{3}\right)_{2} \times 4 \mathrm{H}_{2} \mathrm{O}$, $0.01 \% \mathrm{KNO}_{3}, 0.02 \% \mathrm{MgSO}_{4} \times 7 \mathrm{H}_{2} \mathrm{O}, 10 \%$ sucrose. Germinating pollen grains and pollen tubes were collected after $5 \mathrm{~min}$, $30 \mathrm{~min}$ and $1 \mathrm{~h}$.

TRITC-labelled phalloidin (TRITC-Ph) was dissolved in methanol at $0.05 \mathrm{mg} \mathrm{ml}^{-1}$, and before use in $2 \mathrm{ml}$ of $0.05 \mathrm{M}$ PIPES buffer at $\mathrm{pH} 7.0$ containing $1 \mathrm{mM}$ EGTA, $0.5 \mathrm{mM}$ $\mathrm{MgCl}_{2}$ and $10 \%$ sucrose. The alternative solution contained $1 \%$ or $5 \%$ DMSO (final concentration).

Germinating pollen and the pollen tubes were mounted on the slides in a droplet of medium, containing one droplet of the labelling solution. Samples were covered with cover-glass and used for microscopic observation. Specimens were ob- 
served with a confocal laser scanning microscope (CLSM; model MCR 500; BioRad Instruments, Richmond, Cal., USA) at Siena University. Photographs were made on Ilford PANF 50 ASA.

Living pollen tubes were observed with a Zeiss Axiophot microscope. Photographs were made on Ilford PANF 100 ASA.

\section{RESULTS}

Pollen grains of Ornithogalum virens cultured in vitro in germinating medium initiated the pollen tube after 10-15 minutes of the incubation. At the first stages of the pollen tube growth (within 30 minutes) the speed of growth was 15 $\mu \mathrm{m} / \mathrm{min}$ (for a comparison, in Nicotiana tabacum ca 3 $\mathrm{mm} / \mathrm{min}$ ). Later the pollen tube growth was slower; after 30 minutes of germination the length of the pollen tube was about $400 \mu \mathrm{m}$., and after $1 \mathrm{~h}$ it reached $700 \mu \mathrm{m}$. It should be also noted that these data describe the behavior of the subpopulation of pollen tubes, and data were not analyzed statistically.

We visualized actin using Piersons method (1988) in which $5 \%$ DMSO was applied in the labelling solution. However, we noticed that the application of DMSO in the labelling solution was not optimal for the visualization of actin the pollen grains/tubes of Ornithogalum virens. $5 \%$ concentration of DMSO caused damage of the pollen tubes and $1 \%$ concentration changed the appearance of the labelled actin filaments (Fig. 1). Morphologically they reminded the configuration of actin after cytochalasin treatment or after paraformaldehyde prefixation. During our work we introduced some changes in the method. The modifications concerned the change of the buffer used in the labelling solution: we used PIPES instead of K-phosphate buffer, and we omitted DMSO.

We found that the localization of actin in germinating pollen grains and pollen tubes of Ornithogalum virens using TRITC-labelled phalloidin was possible without DMSO in the labelling solution, and this modification gave the best results. Although the lack of DMSO in the labelling solution initially slowed down the entering TRITC-Ph to the pollen tube cytoplasm, eventually the actin filaments became labelled.

In pollen grains incubated in germinating medium for 5 minutes (Fig. 2a) actin filaments were distributed peripherally in the vicinity of the plasma membrane (Fig. 2b). Observations of optical sections in confocal microscope confirmed the cortical localization of actin filaments. They were short and fine in the appearance, and more concentrated in the aperture region (Fig. 2c).

Pollen tubes germinated within 30 minutes and after $1 \mathrm{~h}$ differed in their length, but in both cases the actin filaments were distributed peripherally in close vicinity to pollen tube plasma membrane (Fig. 3a). One of the interesting features of actin in pollen tubes was its regular distribution. The filaments were numerous and arranged in groups in regular intervals along the pollen tube, especially in the upper part of the pollen tube (Fig. 3b). However some long and thin filaments or filament bundles were observed along the whole length of the pollen tube in the cortical region, as revealed by optical sectioning. Some small aggregates of actin filaments, localized in the cortex, appeared to be star-like - the interesting structures for further analysis (Fig. 3c).

In some cases when observations were made within 20 minutes after addition of the labelling solution, it was possible to see the "fluorescing" actin in the living pollen tube, i.e. the circulatory movement of the cytoplasm in the pollen tube was still intact (Fig. 4).

In pollen grains in which plasmolysis took place (Fig. 5a) the configuration and the appearance of actin filaments was considerably different from those described above (Fig. 2b). The filaments in the plasmolysed pollen grain appeared to be relatively thicker and more abundant (Fig. 5b). Additionally, although they still remained attached to the plasma membrane (detached from the pollen cell wall), they deeply penetrated the cytoplasm of the pollen grain.

Another interesting feature was revealed after mechanical damage of the pollen tube integrity i.e. rupture of the pollen tube cell wall and its membrane which caused the cytoplasm outflow (Fig. 6a). In such cases the distribution and appearance of the actin filaments reminded those observed in the plasmolysed pollen grains (Fig. 6b compare with Fig. 5b). Nevertheless they remained distributed along the pollen cell wall, in the vicinity of plasma membrane. However the cytoplasm fraction which remained inside the pollen tube did not stick to the plasma membrane. This cytoplasm fraction had uneven borders but the actin filaments were regularly localized in the cortical region of the pollen tube in close vicinity of the plasma membrane, under the cell wall. Moreover, the portion of the cytoplasm, which flowed out from the tube, did not contain any actin filaments i.e. they were not revealed by the labelling procedure.

\section{DISCUSSION}

Phalloidin, one of phallotxins, is widely accepted and used to stain specifically actin filaments. It is a cyclic oligopeptide, which affects actin polymerization. It binds to actin filaments stoichiometrically and has the stabilizing effect, decreasing the dissociation constants of filament ends (Wieland 1977).

We modified the method introduced by Pierson (1988), using the buffer solution containing rhodamine labelled phalloidin $(\mathrm{RhLPh})$, without the permeabilizing agent - dimethyl sulfoxide (DMSO). DMSO is widely used to permeabilize the pollen grain/pollen tube plasma membrane and allows the FLPh to enter the cytoplasm.

Since the application of DMSO in the labelling solution appeared not to be optimal for the localization of actin in the pollen grains/tubes of Ornithogalum virens, we postulate, that DMSO being a permeabilizing agent, dissolves some lipids in the plasma membrane, and causes the disorganization of the actin filament alignment in the cortical zone of the pollen tube. The microfilaments in the pollen tube show the peripheral, cortical distribution (in Tiezzi 1991; in Derksen 1995). It is possible that microfilaments in the pollen tube form a sort of cortex structurally connected with plasma membrane by actin-membrane binding proteins. Proteins coupling cytoskeletal elements with the plasma membrane, known as membrane skeleton proteins - annexin, spectrin, ponticulin, were found in plant cells (Michaud et al. 1991; Chia et al. 1993; Seals et al. 1994; Calvert et al. 1996). A spectrin-like protein has been found in the pollen tube plasma membrane (in Derksen et al. 1995). These data suggest the presence of a membrane skeleton which function in plant cells, and in a pollen tube as well, and explain why the use of the permeabilizing agent for investigations of actin would result in the disorganization and the disruption of the the actin cytoskeleton.

Our modification of the standard method allowed the visualization of actin filaments in living pollen tubes of Ornithogalum virens. The actin localization was limited to the apical 

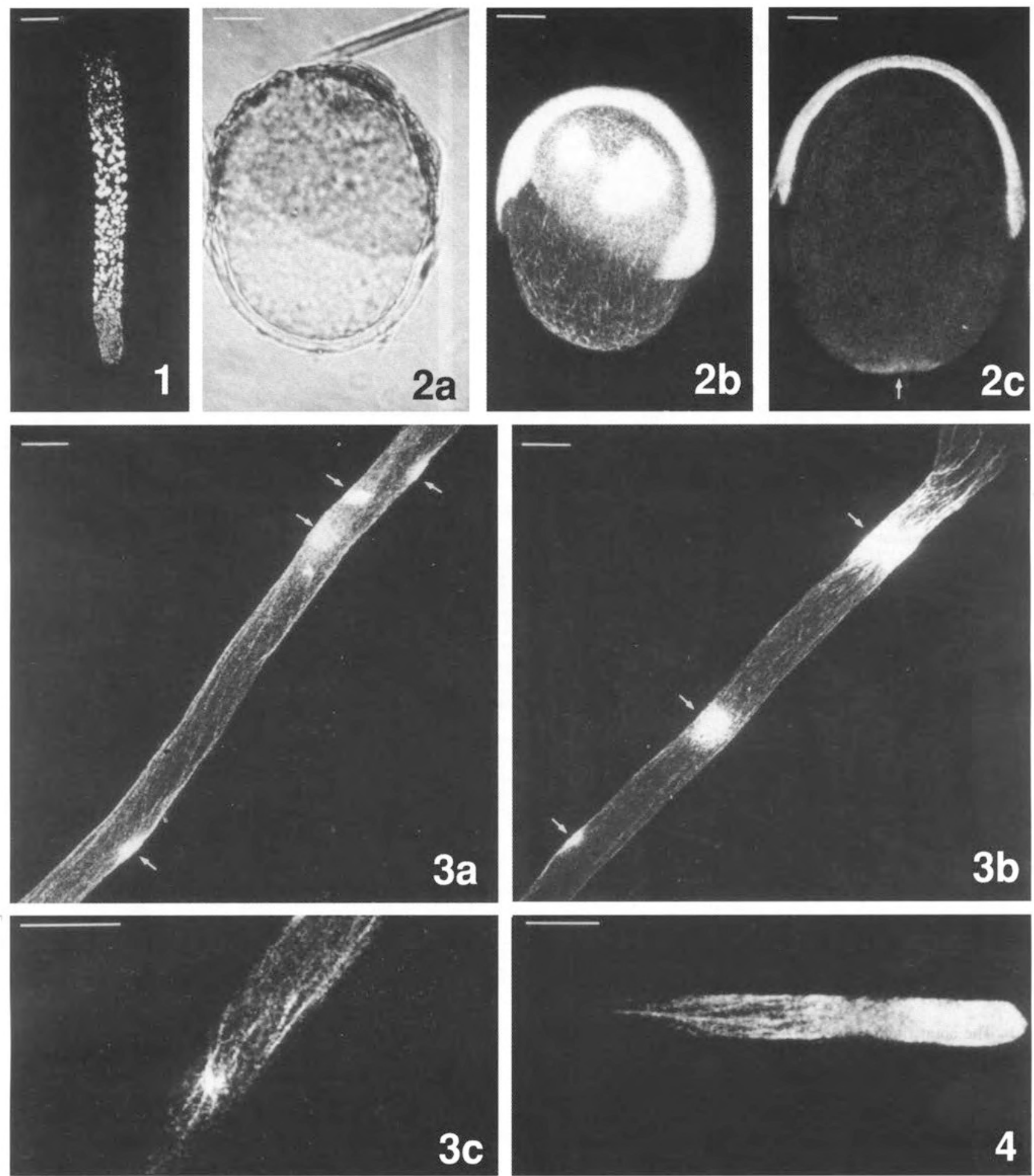

Fig. 1. CLSM image of actin localized in the pollen tube of Ornithogalum virens after application of the labelling solution containing $1 \%$ DMSO. The actin filaments remind the actin configuration after cytochalasin treatment or formaldehyde prefixation. Bar $10 \mu \mathrm{m} ; \mathrm{x} 600$.

Fig. 2a, b, c. The actin filaments localized with use of the modified labelling solution (without DMSO) in pollen grains of Ornithogalum virens incubated in the germination medium for 5 minutes. 2a. The pollen grain image in the transmitted light. 2b. The actin filaments in the pollen grain localized in the vicinity of the plasma membrane/cell wall. 2c. The medial optical X-Y section taken at 0.5 - $\mu \mathrm{m}$ intervals in the Z-direction of the pollen grain with localized actin filaments demonstrating their concentration in the aperture region (arrow). Bar $10 \mu \mathrm{m} ; \mathrm{x} 800$.

Fig. 3a, b, c. The actin filaments localized with use of the modified labelling solution (without DMSO) in the pollen tube of Ornithogalum virens. 3a. The actin filaments in the central part of the tube. The CLSM projection image showing the network of the thin actin filaments distributed in the tube mainly peripherally, in close relation to the plasma membrane/cell wall, with characteristic actin aggregates in the cortical zone (arrows). 3b. The distribution of actin filaments in the upper (aperture) part of the tube - they are more numerous in some regularly spaced groups (arrows). 3c. The peripheral optical X-Y section taken at $0,5-\mu \mathrm{m}$ intervals in the Z-direction showing one of such cortical, starlike actin aggregates. Bar $10 \mu \mathrm{m} ; \mathrm{x} 800$ (3 a, b), x 1600 (3 c).

Fig. 4. The CLSM image of the actin filaments after using the modified labelling solution in the living pollen tube of Ornithogalum virens, in which circulation of the cytoplasm was still intact. The actin filaments were observed just after the application of the labelling solution, so they were visible firstly in the apical area of the tube. Bar $10 \mu \mathrm{m} ; \mathrm{x} 1200$. 

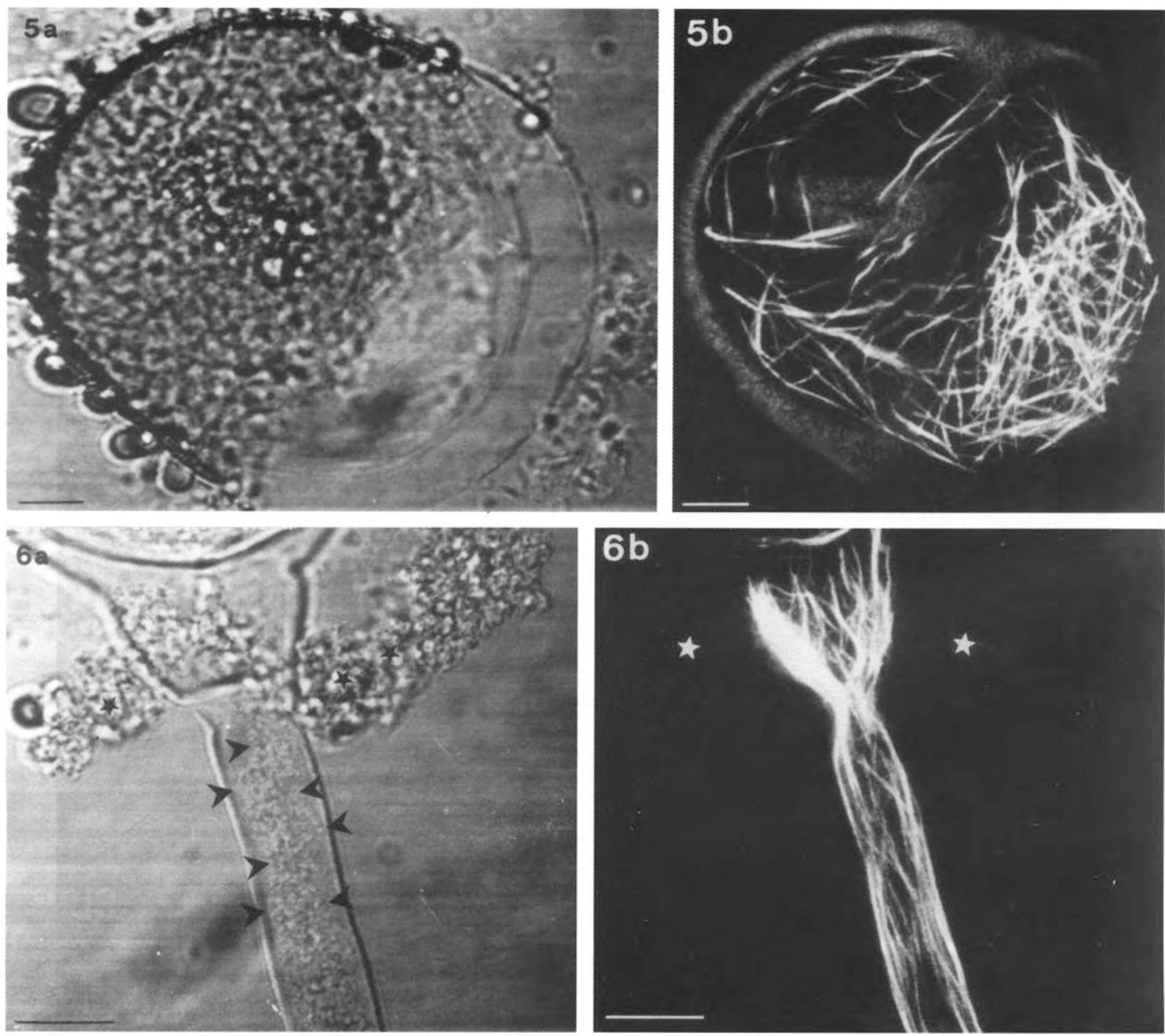

Fig. 5a, b. The actin filaments localized with use of the modified labelling solution (without DMSO) in pollen grains of Ornithogalum virens incubated in the germination medium for 5 minutes, which did not undertake the germination because of the plasmolysis. 5a. The pollen grain image in the transmitted light. 5b. The configuration of the actin filaments in plasmolysed pollen grain. Bar $10 \mu \mathrm{m} ; \mathrm{x} 1000$.

Fig. 6a, b. The actin filaments localized with use of the modified labelling solution (without DMSO) in the pollen tube of Ornithogalum virens germinated for 30 minutes, which had been mechanically damaged. 6a. The pollen tube in the transmitted light; an asterisk indicates the portion of the cytoplasm which had flowed out, and the arrowheads indicate the uneven borders of the remained portion of the cytoplasm in the tube. 6b. The localization of the actin filaments in the same pollen tube - they run along in the cortical zone of the tube remaining adjoined to the plasma membrane/cell wall; asterisks indicate the site of the flown out portion of the cytoplasm (compare with a) where the actin filaments were not detected. Bar $10 \mu \mathrm{m} ; \mathrm{x} 1500$.

region of the tube, and it was observed for a limited period of time (ca $30 \mathrm{~min}$ ). For the first time it was possible to observe actin within the pollen tube simultaneously with the cytoplasmic streaming. The apical localization of actin indicates the participation of the endocytotic process occurring in this zone, which carries out the FLPh transport on the territory of the pollen tube cytoplasm. Other methods of visualizing actin in non-fixed living cells used incubation of the isolated pollen grain protoplasts with solution containing FLPh (Tanaka and Wakabayashi 1992) or microinjection of FLPh solution directly into the characean internodal cells (Wasteneys et al. 1996).
The organization of the actin cytoskeleton in pollen grains of various species, activated for germination, is usually described as a cortical arrangement along the pollen wall, focused upon the germination aperture (Pierson 1988; HeslopHarrison and Heslop-Harrison 1992; Tanaka and Wakabayashi 1992). Our results confirm these data, however some sophisticated differences were observed between the actin cytoskeleton arrangement in pollen grains, which initiated the germination, and in grains in which plasmolysis had occurred. In plasmolysed pollen grains the actin was organized in the form of thick, short bundles. They differ from fine, thin cortical filaments, focused in the aperture region, observed in ger- 
minating pollen. Since the plasmolysis is a separation of the living protoplasmic envelope from the cell wall (in Oparka et al. 1996), which results in decrease of the protoplast volume, our observation would support the thesis that the actin cytoskeleton has some structural relationship with the plasma membrane. It seems improbable, that the rearrangement of the protoplast surface during plasmolysis remains without any changes in the cortical cytoskeleton organization.

The pattern of actin cytoskeleton in pollen tubes of Ornithogalum virens, visualized by FLPh solution, is generally similar to that observed in other species. In pollen tubes of Nicotiana tabacum, Lilium longiflorum, Petunia hybrida, Galanthus nivalis, Narcissus pseudonarcissus, actin, detected with FLPh, was localized also in cortical longitudinal arrays (Perdue and Parthasarathy 1985; Pierson et al. 1986; Pierson 1988; Pierson et al. 1989; Heslop-Harrison and Heslop-Harrison 1989; Heslop-Harrison and Heslop-Harrison 1991). In pollen tubes of several species actin aggregates were observed, in form of short strands of fine radiating webs (Pierson 1988), star-shaped foci (Pierson et al. 1986), or short rods (Perdue and Parthasarathy 1985), which are proposed to correspond to organizing centers of actin filaments. In Ornithogalum virens pollen tubes we observed similar structures, but apart of them, some other aggregates of filamentous actin were observed, too. They appeared in a cortical zone of the tube, and had an ordered arrangement - they formed regularly spaced groups of concentrated actin filaments. However, their function as organizing centers has to be proven. The more probable site of initiation of the actin filament polymerization seems to be located in the apical zone of pollen tube plasma membrane as it is suggested for microtubules (Heslop-Harrison and Heslop-Harrison 1988a, b; Cai et al. 1996). We postulate that the aggregates of actin filaments are sites of their binding to plasma membrane.

\section{ACKNOWLEDGMENTS}

We wish to thank Mrs. B. Bieniak for photographic assistance. This work was supported in part by grant No. 14501/VII BW-1300/33 from the Faculty of Biology of Warsaw University, and No. 2753/95 from the Polish-Italian Scientific Exchange Program granted to $\mathrm{M}$. Stẹpka.

\section{LITERATURE CITED}

BREWBAKER J.L., KWACK B.H. 1963. The essential role of calcium ion in pollen germination and pollen tube growth. Amer. J. Bot. 50: 859-865.

CAI G., MOSCATELLI C., DEL CASINO C., CHEVRIER V., MAZZI M., TIEZZI A., CRESTI M. 1996. The anti-centrosome monoclonal antibody 6C6 reacts with plasma membrane-associated polypeptide of $77 \mathrm{kDa}$ from Nicotiana tabacum pollen tubes. Protoplasma 190: 68-78.

CALVERT C.M., GANT S.J., BOWLES D.J. 1996. Tomato annexins p34 and $\mathrm{p} 35$ bind to F-actin and display nucleotide phosphodiesterase activity inhibited by phospholipid binding. Plant Cell 8: 333-342.

CHIA C.P., SHARIFF A., SAVAGE S.A., LUNA E.J. 1993. The integral membrane protein, ponticulin, acts as a monomer in nucleating actin assembly. J. Cell Biol. 120: 909-922.
CONDEELIS J.S. 1974. The identification of F-actin in the pollen tube and protoplast of Amarylis belladonna. Exptl. Cell res. 88: 435-439.

DERKSEN J., RUTTEN T., VAN AMSTEL T., DE WIN A., DORIS F., STEER M. 1995. Regulation of pollen tube growth. Acta Bot. Neerl. 44 (2): 93-119.

HESLOP-HARRISON J., HESLOP-HARRISON Y. 1988a. Organelle movement and fibrillar elements of the cytoskeleton in the angiosperm pollen tube. Sex. Plant Reprod. 1: 16-24.

HESLOP-HARRISON J., HESLOP-HARRISON Y. 1988b. Sites of origin of the peripheral microtubule system of the vegetative cell of the angiosperm pollen tube. Ann. Bot. 62: 455-461.

HESLOP-HARRISON J., HESLOP-HARRISON Y. 1989. Conformation and movement of the vegetative nucleus of the angiosperm pollen tube: association with the actin cytoskeleton. J. Cell Sci. 93: 299-308,

HESLOP-HARRISON J., HESLOP-HARRISON Y. 1991. The actin cytoskeleton in unfixed pollen tubes following microwave-accelerated DMSO-permeabilization and TRITC-phalloidin staining. Sex. Plant Reprod. 4: 6-11.

HESLOP-HARRISON J., HESLOP-HARRISON Y. 1992. Intracellular motility, the actin cytoskeleton and germinability in the pollen of wheat (Trititcum aestivum L.). Sex. Plant Reprod. 5: 247-255.

LANCELLE S. A., CRESTI M., HEPLER P.K. 1987. Ultrastructure of the cytoskeleton in freeze-substituted pollen tubes of Nicotiana alata. Protoplasma 140: 141-150.

MICHAUD D., GUILLET G., ROGERS P.A., CHAREST P.M. 1991. Identification of a $220 \mathrm{kDa}$ membrane-associated plant cell protein immunologically related to human $\beta$-spectrin. FEBS 294 (1-2): 77-80.

OPARKA K.J., PRIOR D.A.M., CRAWFORD J.W. 1996. Membrane conservation during plasmolysis. In: Membranes: specialized functions in plants. M. Smallwood, J.P. Knox, D.J. Bowles (eds) BIOS Scientific Publishers, Oxford.

PERDUE T.D., PARTHASARATHY M.V. 1985. In situ localization of F-actin in pollen tubes. Eur. J. Cell Biol. 39: 13-20.

PIERSON E.S. 1988. Rhodamine-phalloidin staining of F-actin in pollen after dimethylsulphoxide permeabilization. A comparison with the conventional formaldehyde preparation. Sex. Plant Reprod. 1: 83-87.

PIERSON E.S., CRESTI M. 1992. Cytoskeleton and cytoplasmic organization of pollen and pollen tubes. Int. Rev. Cytol. 140: 73-125.

PIERSON E.S., DERKSEN J., TRAAS J.A. 1986. Organization of microfilaments and microtubules in pollen tubes grown in vitro or in vivo in various angiosperms. Eur. J. Cell Biol. 41: 14-18.

PIERSON E.S., KENGEN H.M. P., DERKSEN J. 1989. Microtubules and actin filaments co-localize in pollen tubes of Nicotiana tabacum L. and Lilium longiflorum Thumb. Protoplasma 150: 75-77.

SEALS D.F., PARRISH M.L., RANDALL S.K. 1994. A 42-kilodalton annexin-like protein is associated with plant vacuoles. Plant Physiol. 106: 1403-1412.

TANAKA I., WAKABAYASHI T. 1992. Organization of the actin and microtubule cytoskeleton preceding pollen germination. An analysis using cultured pollen protoplasts of Lilium longiflorum. Planta 186: 473-482.

TIEZZI A. 1991. The pollen tube cytoskeleton. Electron Microsc. Rev. 4: 205-219.

WASTENEYS G.O., COLLINGS D.A., GUNNING B.E.S., HEPLER P.K., MENZEL D. 1996. Actin in living and fixed characean internodal cells: identification of a cortical array of fine actin strands and chloroplast actin rings. Protoplasma 190: 25-38.

WIELAND T. 1977. Modification of actins by phallotoxins. Naturwissenschaften 64: 303-309. 


\section{LOKALIZACJA AKTYNY W ŁAGIEWKACH ORNITHOGALUM VIRENS L.}

\section{STRESZCZENIE}

Kiełkujące ziarno pyłku (in vivo w słupku lub in vitro na pożywce) tworzy łagiewkę transportującą jądro komórki wegetatywnej i komórkę generatywną/dwie komórki plemnikowe uczestniczące w procesie podwójnego zapłodnienia u roślin okrytozalążkowych. Wzrost łagiewki i transport organelli/komórek zachodzi dzięki działaniu dwóch głównych systemów lokomotorycznych zlokalizowanych w łagiewce pyłkowej roślin wyższych: tubulinowo-dyneinowo-kinezynowego oraz aktynowo-miozynowego. W łagiewce pyłkowej Ornithogalum virens zlokalizowano filamenty aktynowe stosując roztwór zawierający falloidyne znakowaną TRITC $(2 \mu \mathrm{g} / \mathrm{ml})$ rozpuszczoną w buforze PIPES oraz $10 \%$ sacharozę, $\mathrm{z}$ ominięciem etapu utrwalania i stosowania substancji zwiększającej przepuszczalność błony komórkowej (DMSO). Pozwoliło to na uzyskanie dobrze zachowanej struktury: fluoryzująca aktyna była obserwowana w żywej łagiewce pyłkowej. Porównano strukturę i rozmieszczenie zlokalizowanych filamentów aktynowych w normalnie kiełkujących i splazmolizowanych ziarnach pyłku oraz w żywych rosnących łagiewkach i mechanicznie uszkodzonych. Obserwacje w mikroskopie konfokalnym na skrawkach optycznych pozwoliły stwierdzić, iż filamenty aktynowe rozmieszczone są w pobliżu błony komórkowej łagiewki. To mogłoby potwierdzać pogląd, iż filamenty aktynowe są strukturalnie powiązane z plazmalemą i tworzą rodzaj korteksu, przeprowadzającego ruch cytoplazmy i transport organelli oraz komórek.

SŁOWA KLUCZOWE: aktyna, korteks, falloidyna, łagiewka pyłkowa. 